Acetelion, Lilly, Boehringer Ingelheim, Elizabeth Volkmann Grant/research support from: Forbius, Corbus Pharmaceuticals, Consultant of: Boehringer Ingelheim, Forbius, Speakers bureau: Boehringer Ingelheim, Dinesh Khanna Shareholder of: Eicos Sciences, Inc./Civi Biopharma, Inc., Grant/research support from: Dr Khanna was supported by NIH/NIAMS K24AR063120, Consultant of: Acceleron, Actelion, Bayer, Boehringer Ingelheim, Bristol-Myers Squibb, Corbus Pharmaceuticals, Horizon Therapeutic, Galapagos, Roche/Genentech, GlaxoSmithKline, Mitsubishi Tanabe, Sanofi-Aventis/Genzyme, UCB, Daniel Wachtlin Employee of: Employee of Boehringer Ingelheim, Martina Gahlemann Employee of: Employee of Boehringer Ingelheim, Manuel Quaresma Employee of: Employee of Boehringer Ingelheim, Margarida Alves Employee of: Employee of Boehringer Ingelheim, Oliver Distler Grant/research support from: Grants/ Research support from Actelion, Bayer, Boehringer Ingelheim, Competitive Drug Development International Ltd. and Mitsubishi Tanabe; he also holds the issued Patent on mir-29 for the treatment of systemic sclerosis (US8247389, EP2331143)., Consultant of: Consultancy fees from Actelion, Acceleron Pharma, AnaMar, Bayer, Baecon Discovery, Blade Therapeutics, Boehringer, CSL Behring, Catenion, ChemomAb, Curzion Pharmaceuticals, Ergonex, Galapagos NV, GSK, Glenmark Pharmaceuticals, Inventiva, Italfarmaco, iQvia, medac, Medscape, Mitsubishi Tanabe Pharma, MSD, Roche, Sanofi and UCB, Speakers bureau: Speaker fees from Actelion, Bayer, Boehringer Ingelheim, Medscape, Pfizer and Roche

DOI: 10.1136/annrheumdis-2020-eular.2854

\section{THU0331 INTERSTITIAL LUNG DISEASE IN SYSTEMIC SCLEROSIS: DECLINE IN FORCED VITAL CAPACITY DOES NOT PREDICT FURTHER PROGRESSION IN THE FOLLOWING PERIOD}

A. M. Hoffmann-Vold ${ }^{1}$, H. Fretheim ${ }^{1}$, B. Maurer ${ }^{2}$, M. Durheim ${ }^{1}$, Ø. Midtvedt ${ }^{1}$, M. O. Becker ${ }^{2}$, R. Dobrota ${ }^{2}$, Ø. Molberg', S. Jordan ${ }^{2}$, O. Distler ${ }^{2}{ }^{1}{ }^{1}$ Oslo University Hospital, Oslo, Norway; ${ }^{2}$ University Hospital Zurich, Zurich, Switzerland

Background: In systemic sclerosis (SSc) patients with interstitial lung disease (ILD) approximately $30 \%$ show progressive ILD. It is unknown whether a progressive ILD period is followed by further lung function decline. In clinical practice, treatment is frequently initiated after observation of lung function decline over 6-12 months and lung function stabilization at follow up is often interpreted as treatment effect.

Objectives: Assess the predictive ability of lung function decline over 12 months for further deterioration adjusted for known risk factors for ILD and treatment in two large and well characterized SSc cohorts.

Methods: Patients with SSc-ILD by HRCT, fulfilling SSc classification criteria, from the Oslo and Zurich University Hospital were included. The first period with three consecutive annual forced vital capacity (FVC) measurements (i.e. at 0, 12 and 24 months, +/- 3 months) was used. Lung function decline was assessed by absolute changes in FVC\% predicted. Moderately progressive ILD was defined as FVC decline of $>5-<10 \%$ and significantly progressive ILD as FVC decline $\geq 10 \%$ in 12 months. Candidate predictors by experts (including SSc subtype, autoantibodies, disease duration, baseline and FVC decline in the first period, extent of lung and skin (mRSS) fibrosis, CRP, reflux, tendon friction rubs, $\mathrm{O} 2$ desaturation, dyspnea) for FVC decline in the second period were tested using logistic regression analysis. Treatment included low dose corticosteroids, mycophenolate mofetil; and other immunosuppressive treatment (cyclophosphamide, Rituximab and Tocilizumab).

Results: In total, 240 SSc-ILD patients met the inclusion criteria (table). Of these 69 (29\%) SSc-ILD patients showed progressive ILD in the first 12 months period; $34(14 \%)$ with moderate $(5-10 \%)$ and $35(15 \%)$ with significant FVC decline $(\geq 10 \%)$. Independent of FVC changes in the first period, 77 (32\%) showed progressive ILD in the second period; 44 (18\%) moderate and $33(14 \%)$ significant FVC decline. Only 21 (9\%) SSc-ILD patients had two progressive periods, and $115(48 \%)$ were stable in the two 12 month's periods; all independent of treatment. In multivariable logistic regression, progressive ILD in the first period (moderate, significant or combined FVC decline) was not predictive for progression in the following period. Of all applied risk factors, only mRSS was significantly predictive for further FVC decline, also when adjusted for age, gender and treatment (OR 1.03, 95\% Cl 1.00-1.08, $\mathrm{p}=0.035$ ).

Conclusion: Decline of FVC in one 12 months period did not predict further ILD progression in the following 12 months independent of treatment. These results have important clinical implications. Firstly, a decline of lung function in one period seems not to be the right indicator for initiating treatment. Secondly, stabilization of lung function under treatment initiated after ILD progression cannot necessarily be interpreted as a treatment response on the individual patient level.

Table:

\begin{tabular}{|c|c|c|c|c|}
\hline & & First period & Both periods & \\
\hline & $\begin{array}{l}\text { SSc-ILD } \\
(n=240)\end{array}$ & $\begin{array}{l}\text { ILD progres- } \\
\text { sion }(n=69)\end{array}$ & $\begin{array}{l}\text { ILD progres- } \\
\text { sion }(n=21)\end{array}$ & $\begin{array}{l}\text { Stable ILD } \\
(\mathrm{n}=115)\end{array}$ \\
\hline Age, years (SD) & $48(14.7)$ & $49(13.8)$ & $50(14.3)$ & $46(15.3)$ \\
\hline Male, $\mathrm{n}(\%)$ & $57(24)$ & $18(26)$ & $5(24)$ & $27(24)$ \\
\hline Disease duration yrs, mean (SD) & $10.2(11.4)$ & $9.8(10.2)$ & $8.8(11.0)$ & $10.8(12.3)$ \\
\hline Disease duration $<3$ years, $\mathrm{n}(\%)$ & $68(28)$ & $22(32)$ & $8(38)$ & $29(25)$ \\
\hline Diffuse cutaneous SSc, $n(\%)$ & $95(40)$ & $30(44)$ & $11(52)$ & $43(27)$ \\
\hline Anti-topoisomerase I Ab, n (\%) & $84(35)$ & $27(40)$ & $9(43)$ & $42(37)$ \\
\hline mRSS, mean (SD) & $10(9.3)$ & $11(10.2)$ & $16(13.0)$ & $8(8.3)$ \\
\hline CRPml, mean (SD) & $3.6(7.2)$ & $3.3(6.2)$ & $4.4(9.1)$ & $3.1(5.1)$ \\
\hline GERD, n (\%) & $148(62)$ & $44(64)$ & $15(74)$ & $70(61)$ \\
\hline FVC $\%$ predicted & 90 (20.3) & $90(21.9)$ & $92(21.7)$ & $89(19.3)$ \\
\hline $\mathrm{DL}_{\mathrm{co}} \%$ predicted & $64(17.9)$ & $64(16.6)$ & 70 (11.3) & $65(17.5)$ \\
\hline Lung fibrosis >20\%, n (\%) & $55(23)$ & $16(23)$ & $4(19)$ & $27(24)$ \\
\hline Mycophenolate Mofetil, n (\%) & $47(20)$ & $15(22)$ & $5(24)$ & $23(20)$ \\
\hline Other immunosuppression, $\mathrm{n}(\%)$ & $79(33)$ & $22(32)$ & $9(43)$ & $42(37)$ \\
\hline Corticosteroids, & $62(26)$ & $18(26)$ & $8(38)$ & $28(24)$ \\
\hline
\end{tabular}

Disclosure of Interests: Anna-Maria Hoffmann-Vold Grant/research support from: Boehringer Ingelheim, Consultant of: Boehringer Ingelheim, Actelion, Bayer, GlaxoSmithKline, Speakers bureau: Boehringer Ingelheim, Actelion, Roche, Håvard Fretheim: None declared, Britta Maurer Grant/research support from: AbbVie, Protagen, Novartis, congress support from Pfizer, Roche, Actelion, and MSD, Speakers bureau: Novartis, Mike Durheim Grant/research support from: BI, Consultant of: BI, Speakers bureau: BI, Øyvind Midtvedt: None declared, Mike O. Becker: None declared, Rucsandra Dobrota: None declared, Øyvind Molberg: None declared, Suzana Jordan: None declared, Oliver Distler Grant/research support from: Grants/Research support from Actelion, Bayer, Boehringer Ingelheim, Competitive Drug Development International Ltd. and Mitsubishi Tanabe; he also holds the issued Patent on mir-29 for the treatment of systemic sclerosis (US8247389, EP2331143)., Consultant of: Consultancy fees from Actelion, Acceleron Pharma, AnaMar, Bayer, Baecon Discovery, Blade Therapeutics, Boehringer, CSL Behring, Catenion, ChemomAb, Curzion Pharmaceuticals, Ergonex, Galapagos NV, GSK, Glenmark Pharmaceuticals, Inventiva, Italfarmaco, iQvia, medac, Medscape, Mitsubishi Tanabe Pharma, MSD, Roche, Sanofi and UCB, Speakers bureau: Speaker fees from Actelion, Bayer, Boehringer Ingelheim, Medscape, Pfizer and Roche

DOI: 10.1136/annrheumdis-2020-eular.5755

\section{THU0332 ULTRASONOGRAPHIC EVALUATION FOR SALIVARY GLAND INVOLVEMENT IN SYSTEMIC SCLEROSIS}

J. S. Kim ${ }^{1}$, H. S. Kim², K. A. Lee ${ }^{3}{ }^{1}$ Soonchunhyang University Seoul Hospital, Seoul, Korea, Rep. of (South Korea); ${ }^{2}$ Soonchunhyang University Seoul Hospital, Internal Medicine, Seoul, Korea, Rep. of (South Korea);

${ }^{3}$ Soonchunhyang University Seoul Hospital, Interianl Medicine, Seoul, Korea, Rep. of (South Korea)

Background: While salivary gland ultrasound (SGUS) has widely used for evaluating Sjögren's syndrome, information on SGUS findings of systemic sclerosis (SSc) is limited.

Objectives: We aimed to evaluate the salivary gland involvement in patients with SSc using SGUS.

Methods: We consecutively included patients with SSc fulfilling American College of Rheumatology/European League against Rheumatism (ACR/EULAR) 2013 classification criteria, primary Sjögren's syndrome (pSS) fulfilling ACR/ EULAR 2016 classification criteria, and idiopathic sicca syndrome. All patients underwent SGUS examination using the Outcome Measures in Rheumatology (OMERACT) definition of a SGUS scoring system. The hyperechoic bands using 0-3 scoring system (none/ $<25 \%$ of the parenchyma/25-50\% />50\%) and intraglandular power Doppler signal (PDS) were assessed. Hocevar scoring system (0-48) comprising parenchymal echogenicity, homogeneity, hypoechoic areas, hyperechogenic reflections, and clearness of posterior borders were also evaluated.

Results: A total of 147 patients were included in the study: SSc $(n=59)$, pSS $(n=56)$, and idiopathic sicca syndrome $(n=32)$. The proportion of the highest OMERACT grades among the four glands $\geq 2$ were significantly higher in SSc 